\title{
Modularity, Integration and IT Personnel Skills Factors in Linking ERP to SCM Systems
}

\author{
Sock H. Chung ', Hung-Lian Tang ${ }^{2}$, Imtiaz Ahmad ${ }^{3}$
}

\begin{abstract}
This study investigates some underlying technological factors for linking enterprise resource planning (ERP) to supply chain management (SCM) systems. ERP systems serve technological requirements across functional areas within a corporate boundary while SCM systems focus on collaborative relationships with partners in the supply chain, emphasizing business process integration and information sharing through IT. In order to facilitate SCM operations for business planning and decision making, an ERP system must be extensible in terms of support for a range of external constituents in the supply chain. The research reported in this paper investigates these linkages and provides a framework for developing and evaluating SCM processes in order to serve enterprise needs in terms of resource management for scalability, implementation costs and operational efficiency for meeting the business objectives.
\end{abstract}

Keywords: IT personnel skills; supply chain management; enterprise resource planning; integration; modularity.

\footnotetext{
' Associate Professor -College Of Business, Eastern Michigan University 300 W. Michigan Ave Ypsilanti, MI 48197 U.S.A e-mail: Schungl@emich.edu (Corresponding Author) - Tel. (734)487-1215

${ }^{2}$ PhD Professor - College Of Business, Eastern Michigan University, e-mail: hung-lian.tang@emich.edu

${ }^{3}$ PhD Professor - College Of Business, Eastern Michigan University, e-mail: sahmadI@emich.edu
} 


\section{Introduction}

The importance of both ERP and SCM systems to business organizations and academia is well recognized. Recent surveys found that enterprise systems including ERP and SCM represent IT investment options in the foreseeable future (Wailgum, 2008; Hamerman et. el., 2008; Fontanella and Klein, 2009). Researchers have also been investigating links between ERP and SCM systems for organizations (Akkermans et al., 2003; Bose et. el., 2008, Su and Yang, 20I0; Moller, 2005). Because IT has become an integral component in both ERP and SCM, it is worthwhile to explore the underlying IT technological factors in the two major systems for practitioners and academia (Byrd and Davidson, 2003; Davenport and Brooks, 2004; Wieder, Booth, Matolcsy and Ossimitz, 2006; Zeleny, 1986). Firms whose internal operations were only somewhat integrated have been moving to connect their supply chains with their ERP systems in managing the network of all the partners in the business chains (Davenport, 2000; Moller, 2005). Integrating of business information has been a fundamental requirement of the SCM process as well as that of the ERP systems. Integrating and standardizing information flows within the organization has been a major reason many firms implemented ERP systems (Akkermans et al., 2003; Chen 200I). In this context, the information flows for business processes such as purchasing, production and sales in ERP can also be used in SCM between supply chain partners. Even in the early days of ERP systems, a link between ERP and SCM systems was present with information flows in the form of inventory management (Davenport and Brooks, 2004). With ERP system experience firms that also implemented SCM systems perform far better along the supply chain than the ERP firms that do not use additional SCM systems (Wieder, et al., 2006).

After the companies strengthened their relationships at inter-organizational level with previously adopted ERP systems, they are now deploying new IT tools to create and sustain competitive advantage by linking with supply chain partners. Davenport and Brooks (2004) suggested that while ERP systems are internally focused for their organizations, the greatest impact is felt on their supply chain. Corporations now want more from their ERP investment for information storage and exchange in order to accommodate rapidly expanding business requirements throughout their supply chains (Dai, 2008). Many of them have been trying to incorporate SCM applications into their existing ERP systems. Recent ERP systems provide a platform for SCM and firms across the supply chain can adopt the extended system functionality offered by major vendors (Davenport and Brooks, 2004; Moller, 2005; Wieder, Booth, Motolcsy and Ossimitz, 2006). ERP offers the potential of serving IT infrastructure in order to facilitate firms in integrating their supply chains (Themistocleous et. al., 200I). The goal of the integrating SCM with ERP has been well recognized as the enabler for cooperative organizational relationships, effective business processes and high levels of information sharing with the partners (Bowersox, Closs and Stank, 1999; Dai, 2008; Mabert, Sonni and Venkataramanan, 2003). Thus, this study investigates underlying technological factors of the IT infrastructure for linking ERP to SCM systems.

\section{Motivation for Researching ERP/SCM Linkage}

ERP has been evolving continuosly in response to growing business requirements and developments in information technology that have broadened the scope of ERP for business operations. The evolution of ERP has, at the same time, involved enterprise application integration (EAI), connecting business applications distributed in an enterprise, often developed using a variety of platforms that facilitated specific needs (Gable, 2002). With the EAI software ERP systems can be linked to the rest of the existing systems within a firm (Wieder et al., 2006), and partners' systems in their supply chains (Summer, 2005; Loh and Simpson, 2006). However, the EAI applications often had their own specific user interfaces (Wieder et al., 2006). It became necessary to develop an integrated view of the enterprise with a common interface encompassing its distributed units and diverse application platforms. The classical view of an ERP system serving as a backbone for serving the aggregated needs of the enterprise was no longer adequate (Davenport, 2000; Zuckerman, 2005). The enterprise needed to respond to customer requests in a distributed manner, gearing its manufacturing and distribution logistics accordingly. SCM systems emerged for managing this change. SCM could represent a workin-process view of the enterprise i.e. how the enterprise deals with customers in terms of ERP planning capabilities and putting into operations with its resources. In this view, ERP facilitates SCM, and SCM uses and influences 
ERP. ERP allows things to happen in meeting the customer needs and as it meets those needs it may affect ERP view of the enterprise. How well it achieves this goal depends on the connections between ERP and SCM? The findings in this paper demonstrate a strong linkage between ERP and SCM systems with technological factors of modularity, integration, and IT personnel skills.

This study primarily takes a view of SCM as the enterprise front-end that accesses the ERP system as the enterprise back-end in serving the supply chain operations. In this view, SCM is the customer of enterprise resources in terms of business data and processes, and ERP is the supplier of those resources. ERP architects and designers may operate with a complementatry perspective. What are some of the underlying concepts for establishing connections? SCM may be viewed as a system with " $n$ " interconnected enterprise resources. In the performance of a task, it may start at a resource and travel over connections for access to other relevant resources. These connections form a network. In a typical network, each point is connected to other points that are considered as its natural cohort in the performance of enterprise tasks. The minimally connected network allows each resource to be connected to only one other resource. What connections are established depends on the enterprise view of the architecture in terms of access to resources. Some key considerations are cohesion and operational performance. The smallest collection of resources required in any task is considered a cohesive unit or module to be developed as a workhorse for uses in one or more instances of business operations. A system may also be built with modules that can be dynamically configured based on task requirements. Keeping in view the preceding paragraphs in this section, this study proposes to investigate ERP/ SCM linkage in terms of the following three key factors: integration, modularity, and knowledge and skills.

\section{Methodology and Construct of ERP/SCM}

\section{Linkage Factors}

The methodology adopted in this study follows Churchill's (1979) model for defining the technological factors of ERP and SCM systems. Churchill suggested that a thorough literature review and analysis are imperative when specifying factors. First, this study has identified three factors for further investigations. Second, a set of relevant propositions have been developed from the literature review. Third, sample cases from industries have been used to support the research approach. This methodology has been employed in the process of constructing factors for other IT studies (e.g., Turner and Chung, 2005; Lewis, Snyder \& Rainer, 1995). Likewise, the factors of linking ERP and SCM systems have been defined using content analysis of the IT/IS, SCM and organization literature.

Some business developments impacting the extended effort for SCM by a firm are globalization and enterprise-wide standardization. Globalization (or internationalization) has provided the impetus for corporations to transform their worldwide operations into a single entrepreneurial enterprise. For example Oracle Corporation has worked hard to standardize and integrate its systems for achieving efficiency and better global coordination (Ghoshal and Gratton, 2002). Standardizing operating processes has also been a powerful integrating device within a firm and among business partners (Ghoshal and Gratton, 2002). It has been suggested that IT makes these business developments possible for organizations along their supply chains (Byrd and Davidson, 2003; Fawcett, Ellram and Ogden, 2007). In particular, a number of recent IT developments such as Internet and EAI technologies have converged around ERP platforms. These technologies leverage the Internet and EAI technologies for access to ERP modules, and to enable the open flow of information between different systems. For example in 2007 SAP introduced Netweaver platform to link SAP and other non-SAP systems (https://www.sdn.sap.com/irj/sdn).

Earlier Bowersox et. al. (1999) predicted ERP systems integration over supply chains in the long run. Similarly, Shanks, Seddon and Willcoks (2003) argued that ERP provides the core infrastructure for SCM. The focus of ERP has shifted from internal efficiency to SCM integration (Davenport and Brooks, 2004). The SCM integration has shown that it has evolved with ERP systems from simple inventory management systems of the 1960's, to material requirements planning (MRP) systems in the 1970's and manufacturing resource planning (MRPII) systems in the 1980's (Akkermans et al., 2003; McGaughey and Gunasekaran, 2007; Moller, 2005). The IT infrastructure evolution for ERP and SCM systems has helped many companies to adopt component-based software in which a component refers to an element of software that is clearly defined and separable from the rest of the system (Waquespack and Schlano, 2004). ERP systems have been a major impact on existing information systems extended to SCM systems. For example, SAP's mySAP.com is an open collaborative system possibly to integrate SAP and 
non-SAP ERP software. SAP also introduced Advanced Planning and Optimizer (APO) in order to support supply chain initiatives (Anderson, 2003; Olson, 2004). SCM systems appear to require more ERP modules and open systems to support integrated business functions across enterprises. Taking advantages of the underlying technological factors, ERP systems can provide a platform for SCM, and firms have adopted the SCM functionality offered by enhanced ERP systems (Moller, 2005; Sarkis and Gunasekaram, 2003). Most companies want their previously implemented ERP systems to help collaborate or share information with their supply chain partners. Table I identifies some of the key issues relevant to research reported in this paper. The type information indicates whether the issue most closely relates to integration (I), modularity (2), or knowledge and skills (3). A careful review of the topics in this table serves as a basis for research framework.

\begin{tabular}{|c|c|c|}
\hline Reference & Relevant text & Type \\
\hline Akkermans et al., 2003 & the future impact of ERP systems on SCM & 1 \\
\hline A nderson, 2003 & expanded ERP functionality for SCM & 2 \\
\hline Bose, Pal and Ye, 2008 & $\begin{array}{l}\text { integrate ERP and SCM systems, as they work in a } \\
\text { complementary fashion }\end{array}$ & 1 \\
\hline Byrd and Turner, 2001 & $\begin{array}{l}\text { IT personnel skills affect the IT infrastructure flexibility and } \\
\text { competitive position of the organization }\end{array}$ & 3 \\
\hline Byrd and Davidson, 2003 & $\begin{array}{l}\text { possible antecedents of IT impact on the supply chain and its } \\
\text { effect on firm performance }\end{array}$ & 1,3 \\
\hline Byrd et. al, 2004 & $\begin{array}{l}\text { a high level of IT personnd knowledge and skills is } \\
\text { positively related to both flexible IT infrastructure and the } \\
\text { contribution of ERP and SCM systems, and to competitive } \\
\text { advantage }\end{array}$ & 3 \\
\hline Chen 2001 & standardize information flows within the organization & 2 \\
\hline Dai, 2008 & $\begin{array}{l}\text { information storing and exchanging in order to accommodate } \\
\text { rapidly expanding business requirements }\end{array}$ & 3 \\
\hline Davenport and Brooks, 2004 & $\begin{array}{l}\text { the integration between software modules and business } \\
\text { processes has been accomplished with the ERP software } \\
\text { implementation }\end{array}$ & 1,2 \\
\hline Davenport and Brooks, 2004 & $\begin{array}{l}\text { the Internet has brought about revolution in supply chain } \\
\text { thinking }\end{array}$ & 3 \\
\hline Faw cett, Ellram and O gden, 2007 & $\begin{array}{l}\text { simplify and automate business processes adaptability to } \\
\text { business objectives }\end{array}$ & 2 \\
\hline Ghoshal and Gratton, 2002 & $\begin{array}{l}\text { standardize and integrate its systems for achieving efficiency } \\
\text { and better global coordination. }\end{array}$ & 2,1 \\
\hline Hernandez et al., 2008 & $\begin{array}{l}\text { the degree of compatibility positively affects the integration } \\
\text { of various IT platforms among organizations }\end{array}$ & 3 \\
\hline Jones and Y oung, 2006 & examine how organization manage their ERP systems & 1,2 \\
\hline
\end{tabular}




\begin{tabular}{|l|l|l|}
\hline J ones and Y oung, 2006 & examine how organization manage their ERP systems & 1,2 \\
\hline M abert et al., 2003 & $\begin{array}{l}\text { an enabler for cooperative organizational relationships, } \\
\text { effective business processes and high levels of information } \\
\text { sharing with the partners }\end{array}$ & 3 \\
\hline M entzer et al. 2001 & $\begin{array}{l}\text { managing relationships, information, and materials flow } \\
\text { across enterprise borders }\end{array}$ & 1 \\
\hline Moller, 2005 & connect their supply chains with their ERP systems & 1 \\
\hline M otiwalla and Thompson, 2009 & $\begin{array}{l}\text { extend their ERP systems into supply chain with third party } \\
\text { "bolt on" SCM systems. }\end{array}$ & 1,2 \\
\hline Olson, 2004 & expanded ERP functionality for SCM & 2 \\
\hline Sanders, 2005 & $\begin{array}{l}\text { a firm's SCM objective involves a single enterprise view of } \\
\text { multiple business functions and the transformation of } \\
\text { information into knowledge while integrating the firm's } \\
\text { various IT platforms with external suppliers and customers to } \\
\text { share a large amount of information. }\end{array}$ & 2,3 \\
\hline Sarkis and Gunasekaram, 2003 & $\begin{array}{l}\text { the impact of ERP on supply chain management, a taxonomy } \\
\text { of critical factors, and an empirical analysis on ERP } \\
\text { implementation }\end{array}$ & 1 \\
\hline Summer, 2005 & ERP provides the core infrastructure for SCM & 1,2 \\
\hline Su et. el., 2010 & $\begin{array}{l}\text { Analyzing the impact of ERP on SCM with information } \\
\text { integration }\end{array}$ & 1 \\
\hline
\end{tabular}

Table I: Review of ERP/SCM Linkage 
J. Technol. Manag Innov. 20II,Volume 6, Issue I

\section{Key Areas of Investigations and Propositions}

This section reports on four key areas of investigations relevant to our research and makes propositions for effective ERP/SCM linkages.

SCM implementation strategies fostered information sharing, collaboration and decision making among companies in their supply chains. For example the success of Proctor \& Gamble and Wal-Mart relationship is well documented (Davenport and Brooks, 2004). By sharing sales and forecasting data with the SCM system the two companies have effectively managed inventory performance and gained financial benefit. Another frequently quoted successful SCM story is about Dell and IT (e.g., Margretta, 1998). IT has become an integral element in the SCM process (Sanders, 2005). A firm's SCM objective involves a single enterprise view of multiple business functions and the transformation of information into knowledge while integrating the firm's various IT platforms with external suppliers and customers to share a large amount of information. The integrated supply chain should consider linking firms, customers, and suppliers through electronic transactions in order to facilitate the exchange of goods, services and information through both electronic and traditional means. Davenport and Brooks (2004) argued that the availability of ERP systems has made the integration easier.

Although the task of integration is a huge organizational effort, scores of the software ERP modules and processes based on "best practices" (i.e., SAP's production module and PeopleSoft's human resource) in an industry can provide "best" solutions for the firm. In ERP systems a "best practice" is defined as simply the best way to perform a process (Summer, 2005). Firms that initially improved internal processes through ERP have been examining how ERP and other IT solutions can help them improve processes which extend beyond the enterprise to their customers and suppliers (Davenport and Brooks, 2004). For major ERP vendors like SAP and Oracle/ PeopleSoft, integrating entire supply chains has been a long-time goal (Zuckerman, 2005). The interest of this study is in investigating relationships between ERP and SCM systems. Does the ERP implementation link to the SCM solution for organizations across the supply chain? This is a very important question for seeking evidence of ERP/SCM relationship. Thus this study develops a conceptual framework that can be used to investigate the common characteristics of IT infrastructure between ERP and SCM systems with respect to the three technological factors: modularity, integration and IT personnel skills.

First, modularity refers to the degree to which a system's components may be separated and recombined (Schilling, 2000). Duncan (1995) stated that modularity is the ability of the IT infrastructure to add, modify, and remove any software or data components with ease and with no major overall adverse effect. A modular infrastructure allows a wide variety of data, software, and other technologies to be diffused into its overall business structure. It also readily supports the design, development, and implementation of various application functions. Recently the functionality of ERP has been extended to include additional modules to the established core modules for SCM such as customer relationship management, supply chain planning, sales force automation and data warehousing (Dai, 2008; Davenport and Brooks, 2004; Wieder, Booth, Matolcsy and Ossimitz, 2006).

Second, Lawrence and Lorsch (1967) defined integration as the process of coordinating the interrelated activities of groups within and outside the organization in order to obtain unity of effort. Both ERP and SCM involve the integration of business processes and information flows among customers and partners as well as internal operations. Byrd and Turner (200l) further illustrated that IT integration consists of two sub-factors, IT connectivity and IT compatibility. Connectivity is the ability of any technology components to attach to any of the other components inside and outside the organizational environment (Duncan, 1995). Compatibility is the ability to share any type of information across any technology component. At one extreme, only simple text messages can be shared, while at the other extreme, any document, process, service, video, image, text, audio, or a combination of these can be used by any other system, regardless of manufacturer, make, or type (Duncan, 1995). The degree of compatibility positively affects the integration of various IT platformes among organizations (Hernandez et al., 2008). Importantly, more integrated IT ogranizations are able to streamline operations and integrate functions with greater efficiency than less integrateted IT organizations (Pinsonneault and Kraemer, 2002). 
Third, the human IT infrastructure includes human and organizational skills, expertise, competencies, knowledge, commitment values, common pratices, and organizational structure (Lee, Truath and Farwell, 1995; Weill and Broadbent, 1998). IT infrastructure progression such as ERP and SCM systems accompanies an increase in demand for a variety of skills and knowledge from IT personnel. Davenport and Linder (1994) stated that a "robust" IT infrastructure defines an organization where employees are unencumbered in the performance of their respective jobs, both in terms of the available technologies, and the technological knowledge and skills.

Many organizations have considered the development of flexible IT infrastructures a key management concern. A company with the flexible infrastructure has the potential to modify quickly its IT platform to accommodate ERP and SCM systems implementation. This study advances four propositions for examining the three technological factors of modularity, integration and IT personnel skills in the following sections. First three (PI, P2 and P3) propositions address three identified factors, between ERP and SCM systems and a final encompassing proposition ( $\mathrm{p} 4)$, with discussions leading to some conclusions and directions for further research.

Organizations have been utilizing IT platforms to implement their business innovations in order to be responsive to changing environments. Brancheau, Janz and Wetherbe (1996) suggested that an IT platform should support existing applications while adapting to change as a key to long-term enterprise productivity. This IT strategy can provide the firm with tangible benefits and a continuity of business practices. For firms that have already implemented ERP systems, they do not abandon all their existing IT when adopting new systems (Makey, 1998; Themistocleous et al., 200I). While ERP has evolved to be part of SCM solutions, many firms also have attempted to address the supply chain with their existing ERP systems (Davenport and Brooks, 2004; Moller, 2005).

ERP and SCM systems have been implemented among many organizations as part of their unified IT infrastructure responsive to the demand of changing business strategies such centralization and standardization of information and processes. Davenport and Linder (1994) further suggested that a good IT infrastructure should be quantified by its flexibility and robustness to enable change. The issue of flexibility is viewed as a critical capability of IT infrastructure, because many business organizations are facing an ever-increasing rate of change in their competitive environments (Byrd and Turner, 200I). A typical ERP system implementataion is facilitated by a group of IT professionals to integrate all of a firm's internal functions with a set of modules, and share and transfer information (Akkermans et al., 2003; Chen, 200I). Similarly, with the help of IT professionals SCM systems implementation focuses on the integration of various business functions, information and modules for external suppliers and customers. Therefore, this study posits that SCM system solutions have evolved with technological factors of modularity, integration and IT personnel skills.

Modularity relates to the degree to which IT software, hardware, and data can either be seamlessly diffused into the IT infrastructure or easily supported by the infrastructure (Duncan, 1995). Pyoun and Choi (1994) suggested that the modularity is the capacity for coping with internal and external change for an organization. Historically, modularity has been the major factor in adopting all ERP application components easily into a firm's IT infrastructure (Chung and Snyder, 1999). The term "module" delineates functionality and is called a "component" in ERP systems. The modules or components are often quoted as "best practices" by ERP software vendors. Markus and Tanis (1999) argued that the best practices are a powerful reason for firms to adopt ERP systems with modules. For example the design of SAP R/3 is based on business processes such as sales order handling, and material and requirement handling for production. Therefore, not all companies implement all SAP's R/3 modules. While a company might consider its human resource (HR) department's operations by choosing only HR modules, the same one without manufacturing operations would not choose the manufacturing modules such as production planning (PP) and material management (MM). Most ERP software modules have the concept of modularity embedded in order to adopt to the needs of many organizations (Jones and Young, 2006; Themistocleous et al., 200I). Each module alone or a set of modules in an ERP system can be implemented as the entire system itself (Waquespack and Schiano, 2004). 
Firms have been able to extend their ERP systems into supply chain with "bolt on" SCM systems (Moller, 2005; Motiwalla and Thompson, 2009). The term "bolt on" is used with ERP and SCM system jargon for connecting third party applications (Olson, 2004). Both ERP and SCM systems likely require the modularity factor to accommodate more than a set of software modules from different vendors. This approach is called "a best of breed" approach in which a firm adopts the best practice modules from different software vendors (Olson, 2004). In this approach, many organizations have implemented logistics modules from SAP (ERP software vendor), financial module from Oracle (ERP software vendor) and demand planning module from Manugistics (SCM software vendor). These separate modules should reflect business modularity (e.g., accounting, production, financial management, sales order processing, and procurement) with technical modularity (e.g., data, networks and applications) for SCM. This discussion leads to the first proposition $(\mathrm{PI})$ as follows:

\section{PI) Both ERP and SCM systems are composed of standard software modules to support changing business functionalities of firms across their supply chain.}

Due to advances in IT and fierce competition, firms engage in significant levels of integration efforts for standardized financial information, distribution and sales, manufacturing and engineering processes across their supply chains (Porter, 200I). A firm's IT infrastructure for supply chain contributes to the integration on firms' business strategies, as well as front-end and back-end processes across their supply chains. These IT infrastructural capabilities are the essential foundation for internal and external integration across the supply chain (Byrd and Davidson, 2003; Davenport and Brooks, 2004). The integration factor facilitates a firm's sharing and reusing of software applications and data across technology platforms (Byrd and Turner, 200I). The integration between software modules and business processes has been accomplished with the ERP software implementation (Davenport and Brooks, 2004). Specifically, the ERP integration also provides IT users with ease of use, consistency, and uniformity to work with other IT components in the firm.

A firm's ERP system represents a major component of IT infrastructure for integration of many different people, technologies and processes across the supply chain in an organization. Mabert, Sonni and Venkatamanan (2003) argued that one of the most important motivations for manufacturing firms to implement ERP has been to improve interactions and communication with suppliers and customers. Each firm has become a loose collection of business partners that collaborate with manufacturers, logistics companies and distribution firms (Kalakota and Robinson, 1999). An SCM system addresses the connection of complex information and business environments. The system helps all companies involved in standardizing their products to order, manufacture and deliver in real time for customers. The integration of this standardization processes helps ERP vendors sell nonERP software such as customer relationship management and SCM applications to their competitors' customers (Akkermans et al., 2003).

Initially, ERP vendors (i.e., SAP and Oracle) focused on financial, manufacturing and human resource applications began introducing additional SCM functionalities like APO to their products whereas SCM vendors (i.e., i2 and Logility) have done. They are now expanding their functionalities like value chain collaboration module to the area handled by the ERP vendors (Davenport and Brooks, 2004). As the vendors of ERP systems and SCM systems are adding more functionality to their original products, the difference between the two systems has been diminishing and the integrated IT solutions for SCM can be reality (Motiwalla and Thompson, 2009). Extending from ERP, the SCM system internally and externally integrates all business processes throughout a firm's supply chain while maintaining a competitive strategy. This discussion leads to the second proposition (P 2) as follows:

\section{P2) While an ERP system integrates application modules for the firm's internal functionalities, the SCM system uses the ERP system to integrate external suppliers and customers.}

As the value of IT rose in organizations, the role of IT personnel became crucial in using IT for business success. IT cannot be independent of people, because people with IT knowledge and skills play a critical role to apply IT for business benefits (Zeleny, 1986). In addition to technical skills, IT personnel are increasingly expected to have organizational, functional and managerial skills for their organizations' business. Byrd and Turner (200I) have claimed that the IT components are bound to IT infrastructure flexibility with high knowledge and skills of IT personnel in the firm. Recent research has 
suggested that softer skills such as managerial, business, and interpersonal skills are fundamental to software developers, systems analysts, database administrators, and other IT personnel in organizations (Byrd et al., 2004; Leitheiser, 1992). Byrd and Turner (200I) found that IT personnel skills affect the IT infrastructure flexibility and competitive position of the organization.

The IT personnel factor could also directly affect firm's performance. Ross, Beath and Goodhue (1996) demonstrated through several examples that a highperforming IT organization was a prime factor in developing long-term competitiveness and superior profits in several industries. IT personnel were involved in planning to implement ERP and SCM systems, and sharing information and strategies for supply chain collaboration. In a similar context, Byrd et. al (2004) suggested that a high level of IT personnel knowledge and skills is positively related to both flexible IT infrastructure and the contribution of ERP and SCM systems, and to competitive advantage. In practice, when IT personnel facilitate an organization in supply chain to manage implementation, change and share knowledge from intra and inter organizational communications, they also create relationships which can influence the effectiveness of the organization. As shown by these examples, in many of today's organizations across a supply chain, the IT personnel knowledge and skills are regarded as a strategic asset and a direct contributor to the business performance in these companies. Similarly, Byrd and Davidson (2003) found that the quality of IT personnel directly and positively affects the IT impact on the firm's supply chain. It plays a role in achieving linkage between IT and business functions for the organization. The value of IT personnel knowledge and skills to organizations in the supply chain becomes critically important as the strategic value of ERP and SCM systems has been apparent among firms. This discussion leads to the third proposition (P 3 ) as follows:

\section{P3) IT personnel knowledge and skills for the ERP and SCM systems have a positive effect on business performance on supply chains in organizations.}

Collectively, the characteristics of modularity, integration and IT personnel skills determine the flexibility of the IT infrastructure. That is, an organization with high integration and high modularity is viewed as having a highly flexible IT infrastructure. It is evident that both ERP and SCM systems have been developed in terms of the implemented for the three underlying technological factors. Figure I presents a view of the technological factors in linking ERP with SCM systems.

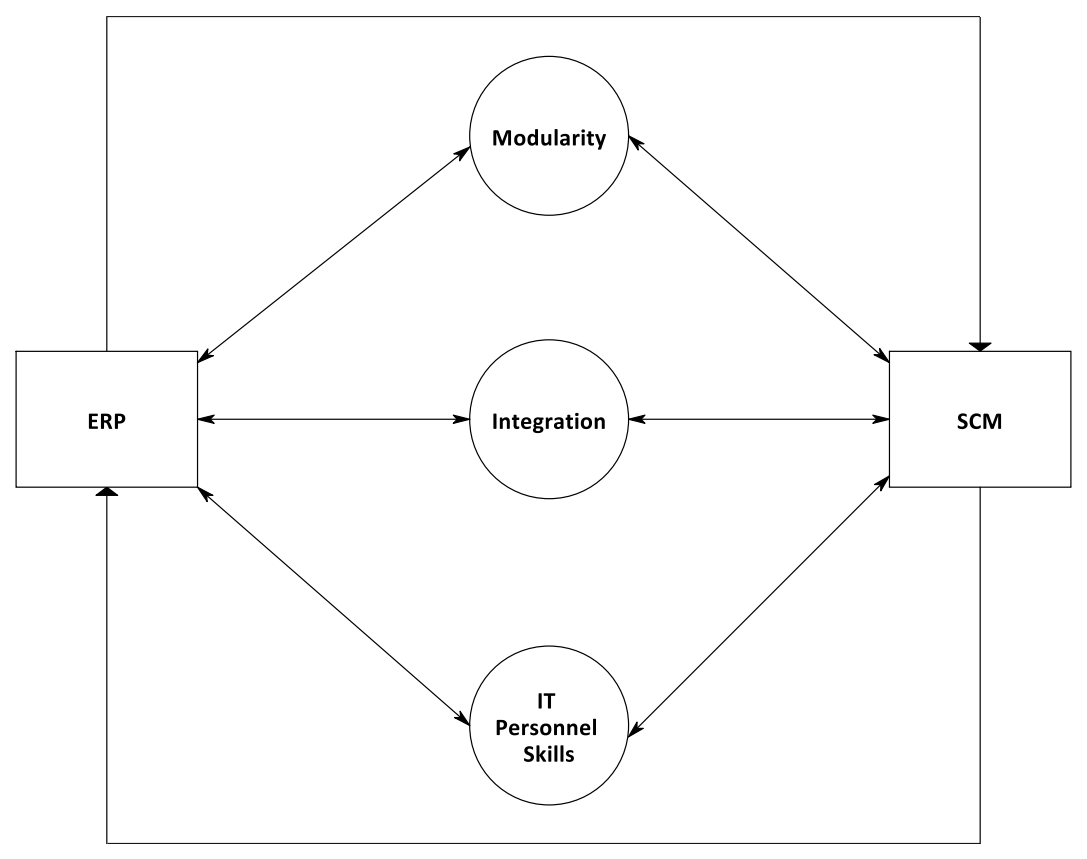

Figure ITechnological Linkage Factors between ERP and SCM

ISSN: 07I8-2724. (http://www.jotmi.org) 
Finally, this study presents an all encompassing proposition (P4) as follows:

\section{P4) The technological factors of Modularity, Integration and IT Personell skills facilitate the implementation of supply chains using an existing ERP system.}

In summary, the following are the key propositions based on the investigations of ERP/SCM requirements. These propositions are intended as guidelines for ERP/SCM researchers and developers.

PI) Both ERP and SCM systems are composed of standard software modules to support changing business functionalities of firms across their supply chain.

P2) While an ERP system integrates application modules for the firm's internal functionalities, the SCM system uses the ERP system to integrate external suppliers and customers.

P3) IT personnel knowledge and skills for the ERP and SCM systems have a positive effect on business performance on supply chains in organizations.

P4) The technological factors of Modularity, Integration and IT Personnel skills facilitate the implementation of supply chains using an existing ERP system.

\section{Conclusion and Future Research}

This study demonstrates linkages between ERP and SCM systems in terms of several IT factors. ERP systems were introduced for managing business resources across many functional areas within a corporation, and are now being enhanced increaseingly to SCM functionality. SCM systems focus on collaborative relationships with partners in the supply chain, emphasizing integration and information sharing through IT. The objectives of SCM in a changing business environment continue to drive the need for extended functionality and openness of ERP modules. It is expected that the functionality differences between ERP and SCM systems will be blurring. This study proposes a framework for investigating the IT infrastructural capabilities of an ERP system to support a firm's SCM initiatives. The three underlying ERP technological factors of modularity, integration and IT personnel skills have been identified to facilitate the integration process for SCM.
What are the implications for corporations and software vendors from the findings of this study? Business managers and IT practitioners should be able to utilize the results of this study in order to focus on enhancing their supply chains with existing ERP systems. This study provides a framework for developing and evaluating SCM processes in order to serve enterprise needs in terms of resource management for scalability, implementation costs and operational efficiency for meeting the business objectives. ERP software vendors should develop their products to be more open and modular for customers to integrate functionality into their SCM initiatives. An ERP system must be extensible for supporting a range of external constituents in the supply chain as a firm's flexible IT infrastructure. Further research is needed for detailed insights on the relationship between ERP and SCM systems in the organizational context. A series of case studies and empirical evidence on firms using ERP and SCM systems is suggested for corporations across the same industry supply chain. Topics to be considered should include the use of ERP platforms implementing SCM for return on investment, outsourcing and organizational structure. More research will validate, amend and elaborate the research questions in greater details explored in this study.

\section{References}

AKKeRMANS, H.A., Bogered, P., Yucesan, E., \& Wassenhove, L.N. (2003). The impmact of ERP on supply chain management: exploratory findings from a European Delphi study, European Journal of Operational Research, I46(20), pp. 284-30I.

ANDERSON, G. W. (2003). SAP Planning: Best Practices in Implementation, Sams Publishing, U.S.A.

BOSE, I., Pal, R., \& Ye, A. (2008). ERP and SCM systems integration: The case of a valve manufacturer in China, Information \& Management, 45(4), pp. 233-24I.

BOWERSOX, D. J., Closs, D. J., \& Stank, T. P. (1999). 21 st century logistics: making supply chain integration reality, Supply Chain Management Review, 3(3).

BRANCHEAU, J.C., Janz, B.D., \&Wetherbe, J.C. (1996). Key issues in information systems management: 1994-95 SIM Delphi results, MIS Quarterly, 20(2), pp. 225-242. 
BYRD, T.A., \& Turner, D. (200I). The impact of IT personnel skills on is infrastructure and competitive IS, Information Resource Management Journal, 17(2), pp. 38-63.

BYRD, T.A., \& Davidson, N.W. (2003). Examining possible antecedents of IT impact on the supply chain and its effect on firm performance, Information \& Management, 4I(2), pp. 243-255.

BYRD, T.A., Lewis, B., \& Turner, D. (2004). An exploratory analysis of the value of the skills of IT personnel: their relationship to IS infrastructure and competitive advantage, Information Resource Management Journal, 32(I), PP. 2I-54.

CHEN, I.J. (200I). Planning for ERP systems: analysis and future trend, Business Process Management Journal, 7(5), Pp. 374-386.

CHUNG, S., \& Snyder, C. (1999). ERP initiation - a historical perspective, Proceedings of the fifth Americas Conference on Information Systems, pp. 213-215.

CHURCHILL, G. A., Jr. (1979). A paradigm for developing better measures of marketing constructs, Journal of Marketing Research, 16, pp. 64-73.

DAI, J. (2008). Supply chain transformation by ERP for enhancing performace: an empirical investigation, Advances in Competitive Research, 16(I-2), pp. 87-98.

DAVENPORT, T.H. (2000). Mission Critical: Realizing the Promise of Enterprise Systems, Harvard Business School Press, Boston, MA.

DAVENPORT, T.H., \& Brooks, J. D. (2004). Enterprise system and the supply chain, Journal of Enterprise Information Management, I7(I), Pp. 8-19.

DAVENPORT, T.H., \& Brooks, J. D. (2004). ERP II: a conceptual framework for next generation enterprise systems, Journal of Enterprise Information Management, I8(4), pp. 483-497.

DAVENPORT, T., \& Linder, J. (1994). Information management infrastructure: the new competitive weapon, Proceedings of the Twenty Seventh Hawaii International Conference on System Sciences, pp. 885896.
DUNCAN, N. B. (1995). Capturing flexibility of information technology infrastructure: a study of resource characteristics and their measure, Journal of Management Information Systems, 12(2), pp.37 57.

FAWCETT, S.E., Ellram, L., \& Ogden, J. (2007). Supply Chain Management From Vision to Implementation, Prenticehall, Upper Saddle River, NJ.

FONTANELLA, J., \& Klein, E. (2008). The supply chain management spending report 2007-2008, AMR Research.

GABLE, J. (2002). Enterprise application integration: EAI is the soluble glue needed for modular relationships that allow organizations to be flexible and respobsive to market, Information Management Journal, 36(2), Pp. 48-5I.

GHOSHAL, S., \& Gratton, L. (2002). Integrating enterprise, MIT Sloan Journal, 44(I), pp. 3I-38.

HAMERMAN, P.D., Moore, C., \& Vitti, R. The stae of ERP 2009: market forces drive specialization, consolidation, and innovation, http://www.forrester.com/rb/Research/ state_of_erp_2009_market_forces_drive/q/id/48390/ t/2 (accessed October 28, 2009).

HERNANDEZ, B., Jimenez, J., \& Martin, M. J. (2008). Business acceptance of information technology: expanding TAM using industry sector and technological compatibility, International Journal of Enterprise Information Systems, 4(4), pp. 62-80.

THE SUPPLY CHAIN COMPANY. http://www.i2.com (accessed February 20, 2009)

JONES, M.C., \& Young, M. (2006). ERP usage in practice: an empirical investigation, Information Resource Management Journal, 19(I), pp. 23-42.

JONES, M.C., \& Young, M. (2006). ERP usage in practice: an empirical investigation, Information Resource Management Journal, 19(I), pp. 23-42.

KALAKOTA, R., \& Robinson, M. (1999). e-Business Roadmap for Success, Addison Wesley Longman, Inc., Reading, MA.

LAWRENCE, P.R., \&Lorsch, J.W. (1967). Organization and Environment. Division of Research, Harvard Business School Press, Boston, MA. 
LEE, D.M.S., Trauth, E.M., \& Farwelll, D. (1995). Critical skills and knowledge requirements of IS professionals: a joint academic/industry investigation, MIS Quarterly, 19(3), pp. 313-340.

LEITHEISER, R.L. (1992). MIS skills for the 1990s: a survey of MIS managers' perceptions, Journal of Management Information Systems, 9(I), pp. 69-9I.

LEWIS, B. R., Snyder, C. A., \& Rainer, R. K. (1995). An empirical assessment of the information resource management construct, Journal of Management Information Systems, 12(I), PP. 199-223.

LOH, S.C.L., \& Simpson, M., (2006). An investigation of the values of becoming an extended enterprise, International Journal ofComputer IntegratedManufacturing, 19(I), pp.49-58.

LOGILITY SOLUTIONS INC. http://www. logility.com (accessed October 2I, 2009).

MABERT, V. A., Sonni, A., \& Venkataramanan, M. A. (2000). Enterprise resource planning survey of U.S. manufacturing firms, Production and Inventory Management Journal, 4I(2), pp. 52-58.

MABERT, V. A., Sonni, A., \& Venkataramanan, M. A. (2003). Enterprise resource planning: Managing the implementation process, European Journal of Operational Research,146(2), pp. 302-314.

MAKEY, P. (1998). Enterprise Resource Planning. Butler Group Limited, Hull, UK.

MARGRETTA, J. (April/March 1998). The power of virtual integration: an interview with Dell Computer's Michael Dell, Harvard Business Review, pp. 73-84.

MARKUS, M. L., \& Tannis, C. (1999). The enterprise systems experience - from adoption to success, R.W.Zmud (ed) Framing The Domains of IT Research: Glimpsing The Future Through The Past, Pinnaflex Educational Resources, Inc., Cincinnati, $\mathrm{OH}$.

MCGAUGHEY, R.E., \& Gunasekaran, A. (2007). Enterprise resource planning: past, present and future, International Journal of Enterprise Information Systems, 3(3), pp. 12-25.
MENTZER, J. T., DeWitt, W., Keebler, J. S., Min, S., Nix, N. W., Smith, C. D., \& et al. (200I). Defining supply chain management, Journal of Business Logistics, 22(2), Pp.I-25.

MOLLER, C. (2005). Unleasing the potential of SCM: adoption of ERP in large Danish enterprises, International Journal of Enterprise Information Systems, I(I), PP. 39-43.

MOTIWALLA, L.F., \& Thompson, J. (2009). Enterprise Systems for Management. Pearson Education, Inc., Upper Saddle River, New Jersey.

OLHAGER, J., \& Selldin, E. (2003). Enterprise resource planning survey of Swedish manufacturing firms, European Journal of Operation Research, 146, pp.365-73.

OLSON, D. (2004). Managerial Issues of Enterprise Resource Planning System. Mcgraw-Hill//rwin, NY, NY.

ORACLE CORPORATION.http://www.oracle.com (accessed November 30, 2009)

PINSONNEAULT, A., \& Kraemer, K.L. (2002). Exploring the role of information technology in organizational downsizing: a tale of two American cities, Organization Science, I3(2), Pp. Pp. 191-208.

PORTER, M.E. (200I). Strategy and the Internet, Harvard Business Review,79, pp. 63-78.

PYOUN, Y. S., \& Choi, B. K. (1994). Quantifying the flexibility value in automated manufacturing systems, Journal of Manufacturing Systems, I3(2), pp.108 188.

ROSS, J.W., Beath, S.M., \& Goodhue, D.L. (1996). Developing long-term competitiveness through IT assets, Sloan Management Review, 38(I), 327-353.

SANDERS, N.R. (2005). IT alignment in supply chain relationships: a study of supplier benefits, Journal of Supply Chain Management, 4I(2), pp. 4-I3.

SAP NETWAEVER CAPABILITIES. https://www.sdn.sap. com/irj/sdn (accessed July 24, 2009).

SARKIS, J., Gunasekaran, A. (2003). Enterprise resource planning--modeling and analysis, Europen Journal of Operational Research, 146(2), pp. 229-232 . 
SHANKS, G., Seddon, P.B., \& Willcoks, L.P. (2003). Second-wave Enterprise Resource Planning Systems: Implementing for Effectiveness. Cambridge University Press.

SCHILLING, M. A. (2000). Toward a general modular systems theory and its application to interfirm product modularity, Academy of Management, 25(2), pp. 3/2-334.

SU, Y.I, \& Yang, C. (2010). A structural equation model for analyzing the impact of ERP on SCM, Expert Systems with Application, 37(I), pp. 456-469.

SUMMER, M. (2005). Enterprise Resource Planning. Prentice Hall, Upper Saddle River, NJ.

THEMISTOCLEOUS, M., Irani, Z., \& O'Keefe, R. (200I). ERP and application integration: exploratory survey, Business Management Journal, 7(3), pp. 195-204.

TURNER, D., \& Chung, S.H. (2005). Technological factors relevant to continuity on ERP foe e-business platform: Integration, Modularity and Flexibility, Journal Internet Commerce, 4(4), pp. II9-132.

WAILGUM, T. (2008). Supply Chain Spending on the rise, http://www.cio.com/article/168700 (accessed January 3, 2008).

WAQUESPACK, L., \& Schiano, W. (2004). Componentbased IS architecture, Information Systems Management, 2I(3), pp. 53-60.

WIEDER, B., Booth, P., Matolcsy, Z.P., \& Ossimitz, M.L., (2006). The impact of ERP systems on firms and business process performance, Journal of Enterprise Information Management, 19(I/2), Pp. 13-29.

WEILL, P., \& Broadbent, M. (1998). Leveraging the new infrastructure. how market leaders capitalize on information technology, Harvard Business School Press, Boston, MA.

ZELENY, M. (1986). High technology management, Human Systems Management, 6(2), pp. 109-120.

ZUCKERMAN, A. (2005). Pushing ERP integration into the supply chain, World Trade, I8(3), pp. 54-55. 